TURIZAM

Volume 25, Issue 1

11-30 (2021)

ORIGINAL

SCIENTIFIC PAPER

\title{
Tourists' Perception of Ecotourism Development in Lagos Nigeria: The Case of Lekki Conservation Centre
}

\author{
Nwokorie Edwin Chigozie ${ }^{\mathrm{A}^{*}}$, Adeniyi Enekole Esther ${ }^{\mathrm{B}}$ \\ Received: July 2020 | Accepted: October 2020 \\ DOI: 10.5937/turizam25-27414
}

\section{Abstract}

This study examined tourists' perception of ecotourism services in Lagos, Nigeria, with the specificity of the Lekki Conservation Centre. Specific objectives were to identify the elements of tourists' demand concerning destination loyalty in the study area. A total of 300 domestic and inbound tourists were sampled, over ten months, using a structured questionnaire. Descriptive statistics were used for data analysis. The findings revealed the availability of vital tourism-related products to meet tourist demand, a conducive tourism atmosphere, and a dispersed location of the species in the conservation center with the availability of quality tourism facilities. However, tourists' perception and experience were poor compared to available infrastructural components. The study concludes that managers of the centre have not employed quality destination management and marketing techniques to improve their image and enhance inbound tourism. Recommendations included the need for the provision of more facilities and species, and an improved means of transportation to enhance tourist accessibility to the centre.

Keywords: destination image, destination loyalty, ecotourism, inbound tourism, sustainable tourism, tourist destination.

\section{Introduction}

Ecotourism is a tourism sub-sector that is growing gradually in Nigeria. In the past decade, international tourist arrivals in Nigeria ranged between 6.11 million in 2010 and 6.01 million in 2015, with a $0.99 \%$ increase from 2009 to 2010 and a $25.28 \%$ increase from 2014 to 2015 . However, a significant decline in the statistics was experienced subsequently as tourist arrivals had a drastic drop of $\mathbf{1 2 . 5 0 \%}$ in 2016 at 5.27 million arrivals in comparison to the previous year (World Data Atlas, 2019). Total tourism revenue between 2017 and 2018 was USD2.615m and USD1.977m, respectively, signifying a growth rate of $-24.4 \%$ from the previous year (CEIC, 2020). Nigeria is blessed with an abundance of natural and manmade tourism resources of astonishing quality (Nwokorie, Adiukwu, 2020). The attractions range from beautiful moun-

A Department of Hospitality Management, The Federal Polytechnic Ilaro, Nigeria; Corresponding author: edwin.nwokorie@federalpolyilaro.edu.ng

B Department of Geography and Environmental Management, University of Ilorin, Nigeria 
tain sceneries, waterfalls, intriguing forests, to exotic birds and animals, exquisite cuisines, as well as intriguing game reserves and conservation centres (Nwokorie, 2015; Ijeomah et al., 2019; Obiora, Nwokorie, 2019). These attractions make the country an emerging and fascinating destination in the West African region.

While it has become imperative for Nigeria to diversify its revenue generation potentials following the recent decline in oil revenue, ecotourism is an aspect of tourism that has great potentials to attract huge foreign exchange from inbound visitations given the right approach. As Ijeomah and Eniang (2018, p.1) observed: "Tourism attractions in Nigeria when developed, properly packaged and promoted can satisfy the curiosity of every kind of tourists; and this will bring about increased revenue generation, local empowerment, foreign exchange earnings, creation of a market for local product and development of infrastructures."

For ecotourism to result in conservation and the wellbeing of the local people, Stronza and Pegas (2008) advised that local communities must enjoy the accrued benefits, including participation in management. While Nwokorie (2015) wrote that ecotourism benefits both visitors and host communities with little or zero impact to the environment, Ijeomah et al. (2019) saw that ecotourism is a facet of environmental tourism that makes a minimal impact on the environment, empowers host communities, respects the culture of the indigenous people and conserves biodiversity. Also, Arowosafe and Oladeji (2017) viewed that eco-tourism is an industry capable of generating employment, improving the standard of living of the host communities, and serving as income earners to the country. Ajayi and Eveso (2017) discussed that tourists' impact on the environment creates a reduction in the disruption of natural habitat and considers the local culture of the attraction visited. In as much as global statistics on tourism revealed that the total international tourism arrivals reached 1.18 billion in 2015 (UNWTO, 2017), a destination's pull factors, such as promotional activities, weather, beaches, scenery, facilities, and attractions are also important influences in setting expectations, and subsequently, in meeting the needs of tourists (Asbollah et al., 2017)

However, a variety of factors could determine patronage and number of visitations to a given destination and particular ecotourism site over a defined period. Visitors' sensitivity to climate, language barriers, accessibility to the ecotourism site, availability of accommodation, cuisine, and similar perception elements could be crucial determinants. Perception can be viewed as the total environment that is cognitively sensed, experienced, and becomes the basis for decision-making (Morin et al., 2009). Perception differs from an individual tourist at any time regarding any tourism product or towards different environmental settings, because perception is strongly linked to psychology and people construct. Their views are based on cognitive processes that capture and organize knowledge, experiences, and information through the senses (Lau, McKercher, 2006). However, Ayeni and Ebohon (2012) ascertained that the way tourists travel from one place to another, their activities and mobility within a specific region, the development of accommodation establishments, the supply of food and beverages, water and energy, and consumption patterns all have impacts at both global and local levels that can undermine tourism destinations from a socio-cultural and environmental point of view. Salako et al. (2018) and Sangpikul (2020) argued that tourists experience, satisfaction, and understanding about ecotourism is hinged on tour guide and the ability to stimulate visitors' interest in the resources in the eco-destination.

In Nigeria, tourists have different views about the destination. Ijeomah et al. (2019) discussed tourists' satisfaction concerning different eco-destinations. Very few of the wildlife in this sector are conserved in different parts of Nigeria because of human activities in the site such as poaching and deforestation affecting ecotourism sites. The human activities is why it 
was necessary to conserve the sites for sustainable development. The implication of not conserving ecotourism sites could lead to the extinction of species (Stronza, Pegas, 2008), and the ecosystem where these species are found are gradually exposed to climate change, so the species could adapt to current climatic condition.

Investment in an ecotourism attraction could be stalled by tourists' perception if resources are improperly harnessed. The expectation should be met while enhancing the visitor experience. Ukabuilu et al. (2018) pointed out that the availability of exotic species, the safety of visitors, accommodation and welfare, visitor-friendly population, transport, and banking are variables that stimulate tourist satisfaction and influence visitors' perception of a destination. Worthy of note is the negative or positive word-of-mouth that could emanate as a result of whatever impression formed at a given destination, post-visit.

\section{Objective of Study}

The study is intended at examining tourists' perception of ecotourism services in Eti-Osa, Lagos, Nigeria (the destination), and identifying the important elements of ecotourism that could enhance tourist demand for improved destination loyalty at Lekki Conservation Centre (the attraction). Specific objectives of this study are to:

1. identify the nature of, and location of tourism assets in the study area

2. examine the relationship between tourists' security and tourist visitation to the study area

3. examine the relationship between the receptiveness of the local population and tourists' length of stay.

\section{Review of related literature}

\section{Ecotourism and the Experience Economy}

Understandably, ecotourism entails a lot, depending on the conceived idea of practitioners and the local society at any given time. Kiper (2013, pp. 774) agreed that ecotourism connotes different meanings to different people, because: "To some, it is the general term that encompasses naturebased adventure, soft adventure, and cultural tourism". As a component of sustainable tourism, ecotourism is seen as responsible tourism to environments with unblemished natural resources with very minimal damage to the environment. Accordingly, the International Ecotourism Society, defined ecotourism as "responsible travel to natural areas that conserves the environment, sustains the well-being of the local people and involves interpretation and education" (TIES, 2015).

Arguably, ecotourism is a vital component of the experience economy. This assertion could be justified by the volume of goods and services generated when tourists travel, and the level at which the lives of the local people are positively affected especially through job creation. Nwokorie and Adiukwu (2020) evaluated the level of entrepreneurship created through the provision of accommodation services for tourists and found out that infrastructural development is equally stimulated. Nwokorie and Igbojekwe (2019) wrote that informal job opportunities are also stimulated for local people through tourist activities within hospitality establishments. Also, Nwokorie and Obiora (2018) found out that hotels and tourism establishments are capable of improving the lives of the local people and stimulating sustainable development goals thereby enhancing the quality of lives within a given environment. 
In ecotourism, the accumulation of diverse experience, however, is a major concern, both for the government, tourism businesses, local people, and the visitors, as tourist behaviour is a major predictor for tourism development. For instance, recent studies discovered that tourists and diners have become destination savvy especially as it concerns gastronomy and the outcome of culinary occasions, which has eventually triggered a contemporary debate on junk foods in the hospitality industry (Ares, Gámbaro, 2007; Alam, Sayuti, 2011; Andersson et al., 2017; Bjork, Kauppinen-Raisanen, 2017). As a result of the gap between food production and service procedures, and consumption, many hotel guests and restaurant customers are considering ethical issues in their food choices to enhance guest experience. This emerging trend has become a consideration for tourists' choice of hotel and restaurant selection in both developed and developing societies (Long, 2017).

Similarly, tourists' behaviours are normally shaped by the emergence of new tourism products and services, as well as emerging trends and new segments that shape the experience influencing the post-travel assessment of tourist destinations and hospitality services (ArtalTur et al., 2019). Therefore, what motivates the tourist for subsequent visits to a destination are tied to their perception of area in terms of the attitude of the local people, the overall satisfaction they derive, fulfilment of their expectation, product quality, critical infrastructure, availability of desired resources, a combination of the components of sustainable tourism to improve the experience, and proximity of tourist site with requisite hospitality services (Juvan et al., 2017; Ukabuilu et al., 2018).

\section{Sustainable Tourism}

Tourism and the various components are expected to stand the taste of time, with recourse to the environment, to allow for future use. A synergy has to exist between visitors (the major users of tourism resources - natural and manmade) and the local people (owners and custodians of the tourism resources). For instance, while tourists are expected to respect the culture of the local people during the visit, residents are equally expected to treat the visiting tourists with esteemed regard. This is necessary for tourism growth because the perceived hostile disposition of the residents could be enough to discourage inbound visitations, whereas desecration of tourist sites (for instance) or pilfering of artifacts by visitors could cause disharmony between visitors and residents thus diminishing the perceived value of the destination. Responsible tourism should enforce a mechanism of connection between the three dimensions of sustainable tourism and the relationships among them, emphasizing the importance of the "stakeholders" in the process (Figgis, Wearing, Neil, 1999; Padin, 2012).

Accordingly, the United Nations Environment Programme (UNEP) and United Nations World Tourism Organization (UNWTO) defined sustainable tourism as "Tourism that takes full account of its current and future economic, social and environmental impacts, addressing the needs of visitors, the industry, the environment, and host communities" (UNEP, UNWTO, 2005, p.12). The implication is that (1) environmental resources should be put to optimal use, (2) viable, long-term economic operations which provide economic benefits to all stakeholders should be ensured, and (3) the socio-cultural authenticity of host communities must be ensured (UNEP, UNWTO, 2005; Padin, 2012; Artal-Tur et al., 2019). The perception of inbound tourists on the overall attitude of the local people towards them, with an approach devoid of exploitation and resentment, is important for tourism to thrive in a given destination. 


\section{Ecotourism Principles}

Ecotourism principles are hinged on fundamental issues relating to waste management, minimization of energy usage, site disturbance, impacts on wildlife, social and environmental impacts on visitors and local populations, and how the interpretation can affect their interactions and understanding of the natural environment (McGuffin, 2017). Two essential factors include the delivery of memorable interpretative experiences to visitors that help raise sensitivity to a destination's political, environmental, and social climates, the recognition of the rights and beliefs of the indigenous people, and work in partnership with them to create empowerment.

Learning about cultural differences helps to build understanding and respect across cultural lines. While residents expect the activities of inbound tourists to favour socio-economic activities and create benefits for conservation in the destination throughout their stay, visiting tourists expect interactions that would help them relate to the values, traditions, customs, and norms of different cultures. This interaction has a huge impact on how tourism affects the local population and influences tourists' perception of the destination. Such interactions, according to Oohlala (2013) include;

i. cultural sustainability - which makes the destination fascinating and different

ii. social sustainability - which makes the destination absorb extra inbound visitations with little or no social disharmony

iii. ecological sustainability - which makes optimal use of environmental resources that constitute a key element of tourism development while maintaining essential and non-essential ecological methods, and helping in the conservation of natural heritage and biodiversity

iv. conservation element - which conserves the diversity of plants and animals including actual species in an attraction

v. local participation element - the mutual interaction between tourists and the local community which is an active decision factor.

vi. education element - which enlightens the new tourist to the cultural norms of the destination being visited

\section{Basic Ecotourism Components}

The functional success of ecotourism depends on the availability of accommodation facilities, amenities, attractions, and accessibility to and from the main attraction (Dekhili, Achabou, 2015). These components are major predictors of successful tourism for a destination. Attractions do not exist in the abstract, and they could be manmade or natural. Available amenities in most situations, including accommodation, could form part of the attraction especially when they are built for aesthetic purposes (Vengesayi et al., 2009; Gisore, Ogutu, 2015). Access to the attraction is also a major consideration for the choice of destination for inbound tourism. Accessibility is mostly considered necessary as it aids the guarantee of security for visitors at a destination (Ukabuilu et al., 2018).

Security is equally essential for successful ecotourism undertakings. Nwokorie and Igbojekwe (2019) pointed out that security is a major concern for business and leisure visitors of a new destination who are not likely to compromise their safety during the stay away from home. More importantly for the visiting tourist is the presence of tour guides who are equally needed for directing visitors around the ecotourism sites (Vengesayi et al., 2009; Orimaye et al., 2018; Uka- 
builu et al., 2018). Tour guides possess experiential knowledge and are an integral part of the ecotourism experience. Apart from providing information on site history and other attributes, they also drive the social and cultural dimensions of the visit with information geared towards suppressing tourists' curiosity, thereby making the tourism activity a worthwhile experience.

The availability of tourist-related services is also a factor that influences sustainable tourism. There are cases where poor accommodation standards affect tourists' product choices and influence visitor perception. Gisore and Ogutu (2015, p. 18) wrote that "there is a lack of harmonized classification, grading, and rating scheme (system) for tourism and hospitality establishments and practitioners leading to the use of contradictory systems with mismatched service and product offers." Efficient transport, competitive prices of related products and services (including catering), other ancillary services (including internet services), as well as the receptiveness of local sellers (especially in dealing with language difficulties) are important factors to consider for successful ecotourism development (Dabour, 2003; Idumah et al., 2009; Asuk, Nchor, 2018).

\section{Methodology}

The study employed a 36-point questionnaire using a four-point Likert rating scale (in rankings of agreement and satisfaction, where applicable) which was premised on relevant literature and survey models of past researchers. The elements of the research instrument are expected to address the research objective and form the basis for testing the research hypotheses. Concerning previous research, the elements of the research instruments were adopted from the studies of Haddle (2005), Chan and Baum (2007), Aluko (2010), Dekhili and Achabou (2015), Gisore and Ogutu (2015), Nwokorie (2015), Handriana and Ambara (2016), Abeli (2017), Nwokorie and Obiora (2018), Orimaye et al. (2018), Ukabuilu et al. (2018), and Cui et al. (2019).

\section{Study Area}

Lekki Conservation Centre (LLC) was established in 1990 by Chevron Corporation for the Nigerian Conservation Foundation (NCF). The conservation centre is located between latitude $6^{\circ} 52$ and $3^{\circ} 54^{\prime}$ north of the Equator and longitude $2^{\circ} 45$ and $4^{\circ} 20^{\prime}$ east of the Greenwich Meridian (Figure 1). In the year 2014, the number of tourists in LLC rose to approximately 28,139 visitors (Nigerian Conservation Foundation, 2016).

Lekki Conversation Centre is in Eti-Osa Local Government Area of Lagos State, Nigeria, with other commercial municipalities surrounding the area, and prospects for marine tourism. The southern part of Eti-Osa is bounded by the Atlantic Ocean, the east is bounded by Ibeju-Lekki, the north by Lagos Lagoon and part of Lagos Mainland and Lagos Island, while the western part of Eti-Osa is bounded by Ojo (Figure 1). Eti-Osa has a population of 983,515 with a population density of 4,506 persons per $\mathrm{km}^{2}-2016$ projections (Lagos Bureau of Statistics, 2016), and a total area of $299.1 \mathrm{~km}^{2}$ - landmass; $154.1 \mathrm{~km}^{2}$ and water; $145 \mathrm{~km}^{2}$ (Lagos Bureau of Statistics, 2016; Salako et al., 2018).

\section{Data Sources}

The population for the study was targeted at inbound tourists from across continents. Initial reconnaissance showed that an average of 100 tourists visited the attraction each day. A sample of 399 was determined from a population of 400 using the Taro Yamane formula for sam- 
ple size (Yamane, 1967). The research instrument was randomly administered and retrieved to and from the respondents, who were willing to complete the questionnaire, over ten months (April 2019 to January 2020). The time lag was due to the intermittent nature of inbound tourist arrivals, which also allowed the study to take responses across occasions and seasons without prejudice to the disposition of respondents to accept the survey.

As part of primary data, the global positioning system (GPS) and the geographical information system (GIS) were used to create a geo-database using Arc GIS 10.3 software, for mapping and specie location. Data were interpolated in which the location was further converted to a map.

\section{Validity and Reliability Analysis}

The pilot study and content validity approach were adopted to attest to the validity of the research instrument. A pilot study question was sent to 54 respondents, and their responses conformed to the actual expectations of the study, thereby considering the instrument as valid for the study.

For the content validity, the researchers ensured that the core variables of the study are represented in the research instrument. Therefore, the elements that defined the content validity of the questionnaire used in this study are that: (1) the questions presented in the research instrument conformed to the research objectives and hypotheses, and (2) all relevant components of ecotourism used for the conceptual assessment of the study have been rationally captured.

With the same group of respondents, stability reliability was used to obtain similar scores with repeated testing in a test-retest procedure that involved administering the same questionnaire to the similar respondents in equivalent conditions over some time (Maars, 2009). The reliability and coefficient results obtained (using Pearson's correlation) showed the reliability of the research instrument at 0.97 (Table 1).

Table 1. Validity and reliability analysis

\begin{tabular}{|c|c|c|}
\hline Cronbach's $\alpha$ & Population & Result \\
\hline .97134 & 54 & Reliable \\
\hline
\end{tabular}

Source: Survey output

\section{Method of Data Analysis}

Inferential statistics were used in analyzing data to determine the means and standard deviation of the responses. Two null hypotheses were formulated for the study concerning the research objective and tested in Chi-square statistics to determine significant relationships between variables. While assuming a 95\% confidence interval and 0.05 assumed significance (2-tailed) at the applicable degree of freedom (df), the decision rule is: accept $\left(\mathrm{H}_{\mathrm{o}}\right)$ if $X^{2} c a l \leq$ $X^{2} t a b$. Accepting $\mathrm{H}_{\mathrm{o}}$ means that there is no significant relationship between two variables, while rejection means that there is a significant relationship (Schawnms, 1994; Egbulonu, 2007; Nwokorie, 2017; Nwokorie, Adiukwu, 2020.). 


\section{Results}

A total of 315 questionnaires were returned, with 300 usable for analysis, representing a $75.19 \%$ response rate from the effective sample size (399). The number of the returned questionnaire is adjudged adequate for the study (Evans et al., 2004).

The questionnaire was divided into three parts for clarity and ease of completion. The first subscale elicited demographic details of respondents, while the second subscale elicited responses bothering on elements of the overall destination loyalty for the attraction which are used in addressing the research objective and hypotheses. The third subscale generated responses for visitors' perception of the quality of tourist services at the attraction, which are equally conditions that engender tourism intentions and destination loyalty.

Demographic information revealed that $63.67 \%$ of the respondents are males and $36.33 \%$ are females. All the respondents are adults with $41.33 \%$ between 18 and 25 years, while the remaining $58.67 \%$ are above 26 years of age. Inbound tourists made up to $77.33 \%$ of the visitors while $22.67 \%$ are local tourists. About $96 \%$ of the visitors have formal education, $38 \%$ have had ecotourism experience in the last five years, and $62 \%$ with ecotourism experience spanning over 5 years (Table 2).

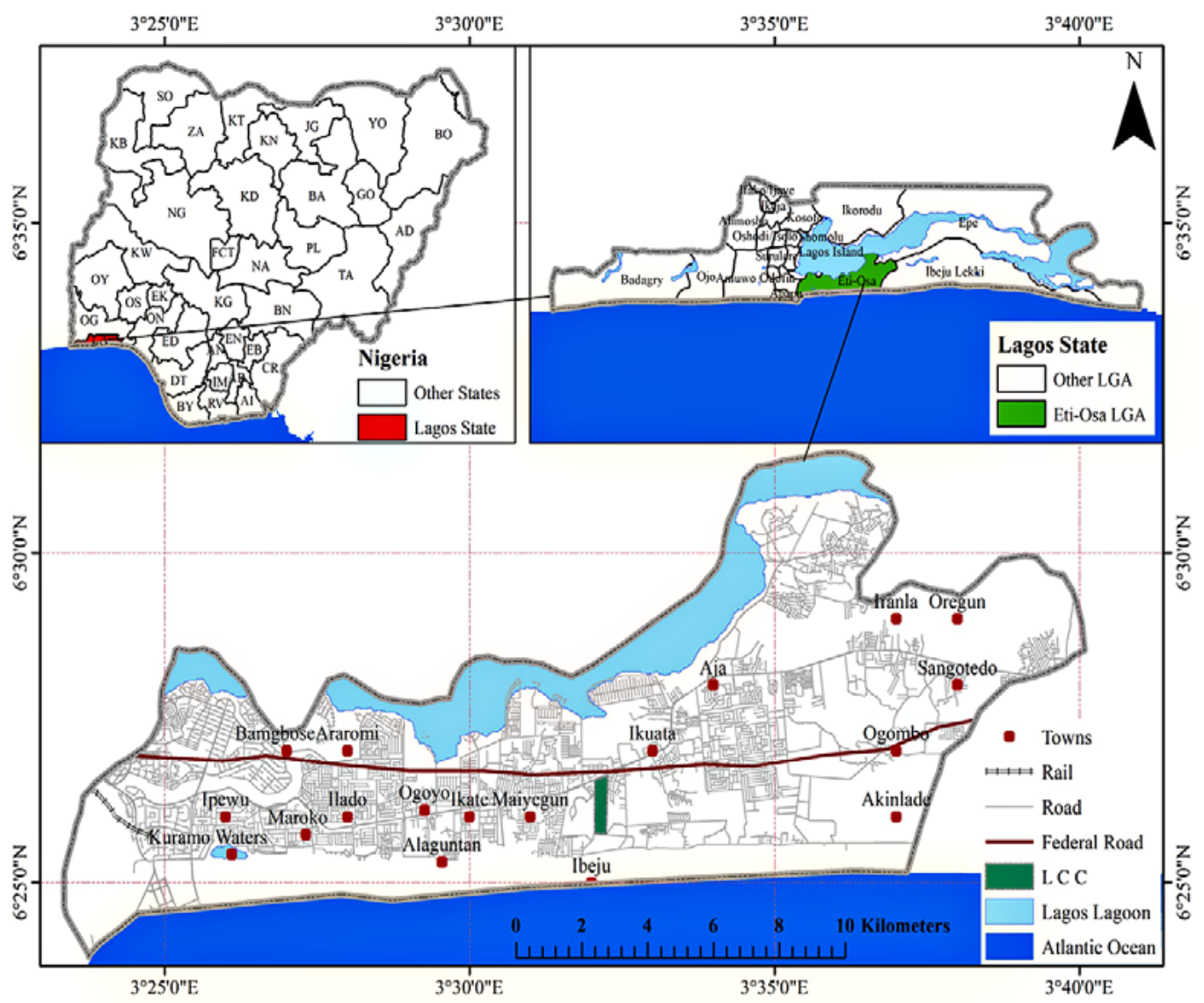

Figure 1. Geographical sketch of the study area Source: Authors' survey 
While the 'strongly agreed' and 'agreed' components of the responses are summed up as affirmative indications, the 'disagreed' and 'strongly disagreed' responses are summed up as negative indications. Similarly, 'very satisfied' and 'satisfied' responses are affirmative indications against the 'dissatisfied' and 'very dissatisfied' responses showing negative indications (Table 3, Table 4).

Table 2. Respondents' demographics

\begin{tabular}{|l|c|c|c|c|}
\hline \multirow{2}{*}{ Item } & \multicolumn{4}{|c|}{ Components \& Responses } \\
\hline \multirow{3}{*}{ 2. Age } & Male & $(\%)$ & Female & $(\%)$ \\
\cline { 2 - 5 } & 191 & 63.67 & 109 & 36.33 \\
\hline \multirow{2}{*}{ 3. Nationality } & $18-25$ years & $(\%)$ & 26 years-above & $(\%)$ \\
\cline { 2 - 5 } & 124 & 41.33 & 176 & 58.67 \\
\hline \multirow{3}{*}{ 4. Education } & Nigerians & $(\%)$ & Non-Nigerians & $(\%)$ \\
\hline \multirow{2}{*}{ 5. Ecotourism experience } & 68 & 22.67 & 232 & 77.33 \\
\cline { 2 - 5 } & Formal & $(\%)$ & Informal & $(\%)$ \\
\cline { 2 - 5 } & 287 & 95.67 & 13 & 4.33 \\
\hline
\end{tabular}

Source: Survey output.

Table 3. Analyses of responses

\begin{tabular}{|c|c|c|c|c|c|c|}
\hline \multirow{2}{*}{ Statement } & \multicolumn{6}{|c|}{ Response } \\
\hline & 4 & 3 & 2 & 1 & a & b \\
\hline 1. Attraction is accessible from the city & $\begin{array}{c}87 \\
29.0\end{array}$ & $\begin{array}{c}103 \\
34.3\end{array}$ & $\begin{array}{c}53 \\
17.7\end{array}$ & $\begin{array}{c}57 \\
19.0\end{array}$ & 2.85 & .585 \\
\hline 2. Transport to the attraction is safe and efficient & $\begin{array}{c}61 \\
20.3 \\
\end{array}$ & $\begin{array}{c}58 \\
19.3 \\
\end{array}$ & $\begin{array}{c}69 \\
23.0 \\
\end{array}$ & $\begin{array}{l}112 \\
37.4\end{array}$ & 2.22 & .577 \\
\hline $\begin{array}{l}\text { 3. Excessive noise (at the attraction) } \\
\qquad \mathrm{H}_{2} \text { component }\end{array}$ & $\begin{array}{c}59 \\
19.67\end{array}$ & $\begin{array}{c}63 \\
21.0\end{array}$ & $\begin{array}{c}97 \\
32.33\end{array}$ & $\begin{array}{c}81 \\
27.0\end{array}$ & 2.33 & .566 \\
\hline 4. Existence of tourist litter & $\begin{array}{c}47 \\
15.67\end{array}$ & $\begin{array}{c}59 \\
19.67\end{array}$ & $\begin{array}{c}89 \\
29.66\end{array}$ & $\begin{array}{c}105 \\
35.0\end{array}$ & 2.16 & .583 \\
\hline 5. Crime rate is minimal & $\begin{array}{c}107 \\
35.67\end{array}$ & $\begin{array}{c}95 \\
31.66\end{array}$ & $\begin{array}{c}83 \\
27.67\end{array}$ & $\begin{array}{l}15 \\
5.0\end{array}$ & 2.98 & .608 \\
\hline 6. Destination is safe and secure & $\begin{array}{c}111 \\
37.0\end{array}$ & $\begin{array}{c}102 \\
34.0\end{array}$ & $\begin{array}{c}55 \\
18.33\end{array}$ & $\begin{array}{c}32 \\
10.67\end{array}$ & 2.97 & .606 \\
\hline 7. Residents' friendliness & $\begin{array}{c}117 \\
39.0\end{array}$ & $\begin{array}{l}108 \\
36.0\end{array}$ & $\begin{array}{c}36 \\
12.0\end{array}$ & $\begin{array}{c}39 \\
13.0 \\
\end{array}$ & 3.01 & .614 \\
\hline 8. Language challenges & $\begin{array}{c}16 \\
5.33 \\
\end{array}$ & $\begin{array}{c}12 \\
4.0 \\
\end{array}$ & $\begin{array}{c}71 \\
23.67 \\
\end{array}$ & $\begin{array}{l}201 \\
67.0 \\
\end{array}$ & 1.48 & .757 \\
\hline 9. Local arts and craft & $\begin{array}{c}74 \\
24.67\end{array}$ & $\begin{array}{c}118 \\
39.33\end{array}$ & $\begin{array}{c}67 \\
22.33\end{array}$ & $\begin{array}{c}41 \\
13.67\end{array}$ & 2.75 & .572 \\
\hline 10. Presence of diverse local culture & $\begin{array}{c}41 \\
13.67\end{array}$ & $\begin{array}{c}64 \\
21.33\end{array}$ & $\begin{array}{c}43 \\
14.33\end{array}$ & $\begin{array}{c}152 \\
50.67\end{array}$ & 1.98 & .616 \\
\hline 11. Available local market & $\begin{array}{c}76 \\
25.33\end{array}$ & $\begin{array}{c}97 \\
32.33\end{array}$ & $\begin{array}{c}117 \\
39.0\end{array}$ & $\begin{array}{c}10 \\
3.34\end{array}$ & 2.80 & .579 \\
\hline
\end{tabular}




\begin{tabular}{|c|c|c|c|c|c|c|}
\hline \multirow{2}{*}{ Statement } & \multicolumn{6}{|c|}{ Response } \\
\hline & 4 & 3 & 2 & 1 & a & b \\
\hline 12. Accommodation & $\begin{array}{c}70 \\
23.33\end{array}$ & $\begin{array}{l}180 \\
60.0\end{array}$ & $\begin{array}{c}40 \\
13.33\end{array}$ & $\begin{array}{c}10 \\
3.34\end{array}$ & 3.03 & .618 \\
\hline $\begin{array}{l}\text { 13. Decent standard of visitor accommodation } \\
\qquad \mathrm{H}_{2} \text { component }\end{array}$ & $\begin{array}{c}62 \\
20.67\end{array}$ & $\begin{array}{l}150 \\
50.0\end{array}$ & $\begin{array}{c}33 \\
11.0\end{array}$ & $\begin{array}{c}55 \\
18.33\end{array}$ & 2.73 & .599 \\
\hline 14. Adequacy of the infrastructure component & $\begin{array}{c}57 \\
19.0\end{array}$ & $\begin{array}{c}35 \\
11.67\end{array}$ & $\begin{array}{c}116 \\
38.66\end{array}$ & $\begin{array}{c}92 \\
30.67\end{array}$ & 2.19 & .581 \\
\hline 15. Prolonged length of stay & $\begin{array}{c}75 \\
25.0\end{array}$ & $\begin{array}{c}130 \\
43.33\end{array}$ & $\begin{array}{c}32 \\
10.67\end{array}$ & $\begin{array}{c}63 \\
21.0\end{array}$ & 2.72 & .570 \\
\hline 16. Ease of entrance (ticketing \& protocol) & $\begin{array}{c}112 \\
37.33\end{array}$ & $\begin{array}{c}71 \\
23.67\end{array}$ & $\begin{array}{c}59 \\
19.67\end{array}$ & $\begin{array}{c}58 \\
19.33\end{array}$ & 2.75 & .577 \\
\hline 17. Quality of tourism assets & $\begin{array}{l}108 \\
36.0\end{array}$ & $\begin{array}{c}114 \\
38.0\end{array}$ & $\begin{array}{c}50 \\
16.67\end{array}$ & $\begin{array}{c}28 \\
9.33\end{array}$ & 3.00 & .612 \\
\hline 18. Proximity to water tourism & $\begin{array}{l}138 \\
46.0\end{array}$ & $\begin{array}{c}97 \\
32.33\end{array}$ & $\begin{array}{c}41 \\
13.67\end{array}$ & $\begin{array}{l}24 \\
8.0\end{array}$ & 2.98 & .608 \\
\hline 19. Availability of exotic species & $\begin{array}{l}108 \\
36.0\end{array}$ & $\begin{array}{c}114 \\
38.0\end{array}$ & $\begin{array}{c}50 \\
16.67\end{array}$ & $\begin{array}{c}28 \\
9.33\end{array}$ & 3.00 & .612 \\
\hline 20. Availability of tour guide & $\begin{array}{c}121 \\
40.33\end{array}$ & $\begin{array}{l}108 \\
36.0\end{array}$ & $\begin{array}{c}42 \\
14.0\end{array}$ & $\begin{array}{l}29 \\
9.67\end{array}$ & 3.07 & .626 \\
\hline $\begin{array}{l}\text { 21. Skills quality (for attraction employees with } \\
\text { whom tourists interact) }\end{array}$ & $\begin{array}{c}121 \\
40.33\end{array}$ & $\begin{array}{l}108 \\
36.0\end{array}$ & $\begin{array}{c}42 \\
14.0\end{array}$ & $\begin{array}{l}29 \\
9.67\end{array}$ & 3.07 & .626 \\
\hline $\begin{array}{l}\text { 22. Two or more visits to the attraction } \\
\qquad \mathrm{H}_{1} \text { component }\end{array}$ & $\begin{array}{c}76 \\
25.33\end{array}$ & $\begin{array}{c}133 \\
44.33\end{array}$ & $\begin{array}{c}31 \\
10.34\end{array}$ & $\begin{array}{c}60 \\
20.0 \\
\end{array}$ & 2.75 & .572 \\
\hline 23. Attraction visibility on the internet & $\begin{array}{c}177 \\
59.0\end{array}$ & $\begin{array}{l}123 \\
41.0\end{array}$ & - & - & 3.59 & 1.247 \\
\hline
\end{tabular}

$\eta=300$

Source: Survey output.

Codes: 4 = Strongly Agreed; 3 = Agreed; 2 = Disagreed; 1 = Strongly Disagreed; $a=$ Mean; $b=$ Standard Deviation .

Decision Rule: Response is negative if mean $(\bar{x}) \leq 2.49$, otherwise response if positive. The decision is based on effective sample size ( $\geq 100)$ for multiple sub-scale/statements and nature of data, as $\bar{x}$ is expected to increase significantly from a lesser degree; hence, the Mean-Value Theorem applies (Egbulonu, 2007; Nwokorie, Obiora, 2018, pp. 129; Nwokorie, Adiukwu, 2020, pp. 22).

Table 4. Tourist perception of the quality of specific tourist services

\begin{tabular}{|c|c|c|c|c|c|c|c|}
\hline \multirow{2}{*}{ Service Quality } & \multicolumn{4}{|c|}{ Responses to the satisfaction level } & \multirow{2}{*}{ a } & \multirow{2}{*}{ b } & \multirow{2}{*}{ c } \\
\hline & 4 & 3 & 2 & 1 & & & \\
\hline 1. Security & $\begin{array}{c}111 \\
37.0\end{array}$ & $\begin{array}{c}102 \\
34.0\end{array}$ & $\begin{array}{c}55 \\
18.33\end{array}$ & $\begin{array}{c}32 \\
10.67\end{array}$ & 2.97 & .606 & 1 \\
\hline 2. Parking space & $\begin{array}{c}57 \\
19.0\end{array}$ & $\begin{array}{c}35 \\
11.67\end{array}$ & $\begin{array}{c}116 \\
38.66\end{array}$ & $\begin{array}{c}92 \\
30.67\end{array}$ & 2.19 & .581 & 2 \\
\hline 3. Tour guide & $\begin{array}{c}121 \\
40.33\end{array}$ & $\begin{array}{l}108 \\
36.0\end{array}$ & $\begin{array}{c}42 \\
14.0\end{array}$ & $\begin{array}{c}29 \\
9.67\end{array}$ & 3.07 & .626 & 6 \\
\hline 4. Transport & $\begin{array}{c}61 \\
20.3\end{array}$ & $\begin{array}{c}58 \\
19.3\end{array}$ & $\begin{array}{c}69 \\
23.0\end{array}$ & $\begin{array}{c}112 \\
37.4\end{array}$ & 2.22 & .577 & 7 \\
\hline 5. Relaxation area/centre & $\begin{array}{c}108 \\
36.0\end{array}$ & $\begin{array}{c}114 \\
38.0\end{array}$ & $\begin{array}{c}50 \\
16.67\end{array}$ & $\begin{array}{c}28 \\
9.33\end{array}$ & 3.00 & .612 & 4 \\
\hline 6. Games & $\begin{array}{c}81 \\
27.0\end{array}$ & $\begin{array}{c}92 \\
30.67\end{array}$ & $\begin{array}{c}89 \\
29.67\end{array}$ & $\begin{array}{c}38 \\
12.66\end{array}$ & 2.72 & .570 & 3 \\
\hline
\end{tabular}




\begin{tabular}{|l|c|c|c|c|c|c|c|}
\hline \multirow{2}{*}{ Service Quality } & \multicolumn{3}{|c|}{ Responses to the satisfaction level } & \multirow{2}{*}{ a } & \multirow{2}{*}{ b } & \multirow{2}{*}{ c } \\
\cline { 2 - 7 } & $\mathbf{4}$ & $\mathbf{3}$ & $\mathbf{2}$ & $\mathbf{1}$ & & & \\
\hline \multirow{2}{*}{ 7. General environment } & 134 & 131 & 21 & 14 & \multirow{2}{*}{3.28} & .715 & 5 \\
\hline \multirow{2}{*}{ 8. Culinary experience } & 44.67 & 43.67 & 7.0 & 4.66 & & & \\
& 184 & 105 & 4 & 7 & \multirow{2}{*}{3.55} & .766 & 8 \\
\hline
\end{tabular}

$\eta=300$.

Source: Survey output.

Codes: 4 = Very satisfied; 3 =Satisfied; $2=$ Dissatisfies; $1=$ Very Dissatisfied; $a=$ Mean; $b=$ Standard Deviation; $c=$ Ranking

\section{Hypotheses}

$\mathrm{H}_{1}$ : There is no relationship between tourists' security and tourist visitation to the study area. $\mathrm{H}_{2}$ : There is no relationship between the receptiveness of the local population and tourists' length of stay.

Table 5. Hypotheses Result

\begin{tabular}{|c|c|c|c|c|c|}
\hline $\mathrm{H}_{0}$ & $\mathrm{df}$ & $\begin{array}{c}\text { Asymp. Sig. } \\
\text { (2-tailed) }\end{array}$ & $\mathrm{X}^{2}$ tab & $\mathrm{X}^{2}$ cal & Decision \\
\hline $\mathrm{H}_{1}$ & 1 & 0.05 & 3.841 & 94.75 & Rejected \\
\hline \multicolumn{7}{|c|}{ Data elements for $\mathrm{H}_{1}=$ Table 3, item 5\&22 } \\
\hline $\mathrm{H}_{2}$ & 3 & 0.05 & 7.814 & 94.46 & Rejected \\
\hline \multicolumn{7}{|c|}{ Data elements for $\mathrm{H}_{2}=$ Table 3, item 3,7,13\&15 } \\
\hline
\end{tabular}

Source: Survey output

\section{Discussions}

Mean $(\overline{\mathrm{x}})$ and standard deviation $\left(\sigma_{\overline{\mathrm{x}}}\right)$ were calculated for the responses to define the evenness of data distribution, the consequent closeness, and the statistical significance of the responses. Generally, the standard deviation of the responses showed that there are fewer variations in the data, hence the result is standard and statistically significant.

In Table 3, respondents affirmed that the attraction is accessible from the city with $63.3 \%$ $\left(\overline{\mathrm{x}} 2.58 ; \sigma_{\overline{\mathrm{x}}} .586\right)$. However, they disagreed that transport to the attraction is safe and efficient with a negative response of up to $60.4 \%\left(\overline{\mathrm{x}} 2.22 ; \sigma_{\overline{\mathrm{x}}} .577\right)$. Prideaux (2000) stated that an inefficient transport system in preferred destinations has the likelihood of causing tourists to seek alternative destinations. While Sorupia (2005) harped on the need for planning to improve the system of catering for the needs of tourists such as easing their movement, the right accommodation, food, and the types of activities offered, Dinu (2018) noted that there would not be effective tourism without efficient transport.

Excessive noise and the existence of tourist litter were negatively indicated with $59.33 \%$ and $64.66 \%\left(\bar{x} 2.33 ; \sigma_{\bar{x}} .566\right.$ and $\left.\bar{x} 2.16 ; \sigma_{\bar{x}} .585\right)$ respectively. Han et al. (2017) found out that noise problem tends to undermine tourists' revisit rate and recommendations. Also, Krelling et al. (2017) linked destination loyalty of various categories of tourists to the existence of debris, in 
which a significant rise in beach debris forced beach tourists to look elsewhere when searching for a vacation in a coastal region.

This study found out that the destination is safe for ecotourism experience. Respondents affirmed a minimal level of crime, with tourist safety and security having positive responses of $67.33 \%$ and $71.0 \%\left(\bar{x} 2.98 ; \sigma_{\bar{x}} .608\right.$ and $\left.\bar{x} 2.97 ; \sigma_{\bar{x}} .606\right)$ in that regard. Nwokorie et al. (2014) and Santos et al. (2018) indicated security as a major determinant of destination loyalty. Fortunately for the present study, the perception of respondents on the security status of LLC is significantly positive.

The residents of the destination were found to be receptive $\left(75.0 \% ; \overline{\mathrm{x}} 3.01 ; \sigma_{\overline{\mathrm{x}}} .614\right)$ while tourists face minimal language barriers $\left(9.33 \% ; \overline{\mathrm{x}} 1.48 ; \sigma_{\overline{\mathrm{x}}} .757\right)$. These are positive indicators for destination loyalty (Gisore, Ogutu, 2015; Marković, Klarić, 2015; Kyzy, Öztüre, 2018; Stronza, Hunt, Fitzgerald, 2019). The availability of local art and craft was also indicated for the destination with up to $64.0 \%$ affirmative response $\left(\overline{\mathrm{x}} 2.75 ; \sigma_{\overline{\mathrm{x}}} .572\right)$. However, the presence of diverse local culture was elusive to a little extent at the destination, as respondents made $65.0 \%\left(\overline{\mathrm{x}} 1.98 ; \sigma_{\overline{\mathrm{x}}} .616\right)$ negative indications to that effect. Culture is a viable ingredient for sustainable tourism (Zhuang et al., 2019), and it is perceived as a major motivator for inbound tourism (Ukabuilu et al., 2018).

Availability of local markets and decent tourist accommodation received positive perceptions from respondents with statistically significant responses $(57.66 \%$; $83.33 \%$ and $70.67 \% ; \overline{\mathrm{x}}$ $2.80, \bar{x} 3.03$ and $\bar{x} 2.73 ; \sigma_{\bar{x}} .579, \sigma_{\bar{x}} .618$ and $\left.\sigma_{\bar{x}} .599\right)$. These are also indices that determine tourists' length of stay at a destination (Roy, Saxena, 2020) which are also reflected in tourists' length of stay in the present study, with $68.33 \%$ positive response for a prolonged length of stay $\left(\overline{\mathrm{x}} 2.72 ; \sigma_{\overline{\mathrm{x}}}\right.$ .570 ). However, respondents believed that the tourism infrastructure component is inadequate with $69.33 \%$ negatives $\left(\overline{\mathrm{x}} 2.19 ; \sigma_{\overline{\mathrm{x}}} \cdot 581\right)$. Tourism infrastructure is a major consideration for tourists' destination choice as well as a strong determinant for tourism development and tourists' intention to stay longer (Jovanović, Ilić, 2016; Roy, Saxena, 2020).

Furthermore, ease of entrance at the attraction received $61.0 \%$ positive responses $\left(\bar{x} 2.75 ; \sigma_{\bar{x}}\right.$ .577 ), quality of tourism assets had $74.0 \%$ affirmative responses $\left(\overline{\mathrm{x}} 3.0 ; \sigma_{\overline{\mathrm{x}}} .612\right)$, while proximity to marine tourism recorded $78.33 \%$ positive responses $\left(\overline{\mathrm{x}} 2.98 ; \sigma_{\overline{\mathrm{x}}} .608\right)$. These factors have been shown to influence tourist perception of destination quality, which are also determinants of destination loyalty (Dabour, 2003; Bankole, 2013; Ursache, 2015; Guri, 2016; Ukabuilu et al., 2018; Stronza et al., 2019).

Respondents affirmed the availability of exotic species at the attraction with $74.0 \%$ positive responses $\left(\overline{\mathrm{x}} 3.00 ; \sigma_{\overline{\mathrm{x}}} .612\right)$, which are of special interest to ecotourists at tropical destinations (Stronza, Pegas, 2008; Hakim, 2017). The availability of tour guides and the presence of skilled attraction employees were also indicated with similar responses in the affirmative $(76.33 \% ; \bar{x}$ 3.07; $\left.\sigma_{\overline{\mathrm{x}}} .626\right)$. Tourists recognize tour guidance as an important element in the tourism experience (Yamada, 2011; Sandaruwani, Gnanapala, 2016; Sangpikul, 2020), hence the necessity of putting tour guidance in the mix should not be underemphasized. While $69.66 \%$ of the tourists responded that they have visited the attraction more than once, which is an indication that the study area possesses a reasonable level of destination loyalty, all the respondents affirmed to the visibility of the attraction on the internet. The internet visibility conforms to the enhancement of destination loyalty for ecotourism resources through their online presence, as found out by Obiora and Nwokorie (2019).

On tourists' perception of the quality of specific services, variables of security, tour guide, relaxation facilities, games, the general environment, and culinary experience received affirmative satisfactory responses with mean scores above 2.50. However, the mean score for parking space and transport is less than 2.50 (Table 4). 


\section{Test of Hypotheses}

$\mathrm{H}_{1}$ was tested at 0.05 significant level. At $1 d f, X^{2} t a b$ is 3.841 while $X^{2} c a l$ is 94.75 . Consequently, $\mathrm{H}_{1}$ was rejected to assert that there is a relationship between tourists' security and tourist visitation to the study area. A test of $\mathrm{H}_{2}$ was carried out at 0.05 significant level. At $3 d f, X^{2} t a b$ is 7.814 while $X^{2} \mathrm{cal}$ is 94.46 . The hypothesis was rejected to affirm that there is a relationship between the receptiveness of the local population and tourists' length of stay for the study.

\section{Location of Species at LLC}

The different locations where exotic species of animals were found, at the time of the study, using the GPS and interpolated are indicated (Table 6, Figure 2).

Table 6. Coordinates for the Location of Species

\begin{tabular}{|c|c|c|}
\hline Species & Longitude & Latitude \\
\hline Locust bean tree & $6^{\circ} 26^{\prime} 10.90^{\prime \prime} \mathrm{N}$ & $3^{\circ} 32^{\prime} 9.14^{\prime \prime} \mathrm{E}$ \\
\hline Tortoise & $6^{\circ} 26^{\prime} 29.26^{\prime \prime} \mathrm{N}$ & $3^{\circ} 32^{\prime} 7.92^{\prime \prime} \mathrm{E}$. \\
\hline \multirow{3}{*}{ Crocodile } & $6^{\circ} 26^{\prime} 15.20^{\prime \prime} \mathrm{N}$ & $3^{\circ} 32^{\prime} 13.19^{\prime \prime} \mathrm{E}$ \\
& $6^{\circ} 26^{\prime} 4.40^{\prime \prime} \mathrm{N}$ & $3^{\circ} 32^{\prime} 13.19^{\prime \prime} \mathrm{E}$ \\
& $6^{\circ} 26^{\prime} 0.88^{\prime \prime} \mathrm{N}$ & $3^{\circ} 32^{\prime} 11.22^{\prime \prime} \mathrm{E}$ \\
\hline \multirow{5}{*}{ Snake } & $6^{\circ} 26^{\prime} 24.13^{\prime \prime} \mathrm{N}$ & $3^{\circ} 32^{\prime} 5.27^{\prime \prime} \mathrm{E}$ \\
& $6^{\circ} 26^{\prime} 28.48^{\prime \prime} \mathrm{N}$ & $3^{\circ} 32^{\prime} 3.10^{\prime \prime} \mathrm{E}$ \\
& $6^{\circ} 26^{\prime} 14.11^{\prime \prime} \mathrm{N}$ & $3^{\circ} 33^{\prime} 28.06^{\prime \prime} \mathrm{E}$ \\
& $6^{\circ} 25^{\prime} 50.07^{\prime \prime} \mathrm{N}$ & $3^{\circ} 32^{\prime} 9.33^{\prime \prime} \mathrm{E}$ \\
& $6^{\circ} 26^{\prime} 8.90^{\prime \prime} \mathrm{N}$ & $3^{\circ} 32^{\prime} 13.07^{\prime \prime} \mathrm{E}$. \\
\hline \multirow{5}{*}{ Monkey } & $6^{\circ} 25^{\prime} 48.02^{\prime \prime} \mathrm{N}$ & $3^{\circ} 32^{\prime} 4.76^{\prime \prime} \mathrm{E}$ \\
& $6^{\circ} 25^{\prime} 49.64^{\prime \prime} \mathrm{N}$ & $3^{\circ} 32^{\prime} 12.71^{\prime \prime} \mathrm{E}$ \\
& $6^{\circ} 26^{\prime} 5.76^{\prime \prime} \mathrm{N}$ & $3^{\circ} 32^{\prime} 3.55^{\prime \prime} \mathrm{E}$ \\
& $6^{\circ} 25^{\prime} 10.41^{\prime \prime} \mathrm{N}$ & $3^{\circ} 32^{\prime} 10.42^{\prime \prime} \mathrm{E}$ \\
& $6^{\circ} 26^{\prime} 18.68^{\prime \prime} \mathrm{N}$ & $3^{\circ} 32^{\prime} 6.76^{\prime \prime} \mathrm{E}$ \\
& $6^{\circ} 26^{\prime} 24.74^{\prime \prime} \mathrm{N}$ & $3^{\circ} 32^{\prime} 12.27^{\prime \prime} \mathrm{E}$ \\
& $6^{\circ} 26^{\prime} 27.44^{\prime \prime} \mathrm{N}$ & $3^{\circ} 32^{\prime} 11.71^{\prime \prime} \mathrm{E}$. \\
\hline
\end{tabular}

Source: Survey output

In the northern part of the attraction, animal species are dispersed than in the southern part. They include monkeys, crocodiles, and snakes, among others. By implication, the spatial distribution of animal species in the attraction is not uneven (Figure 2, Figure 3). 


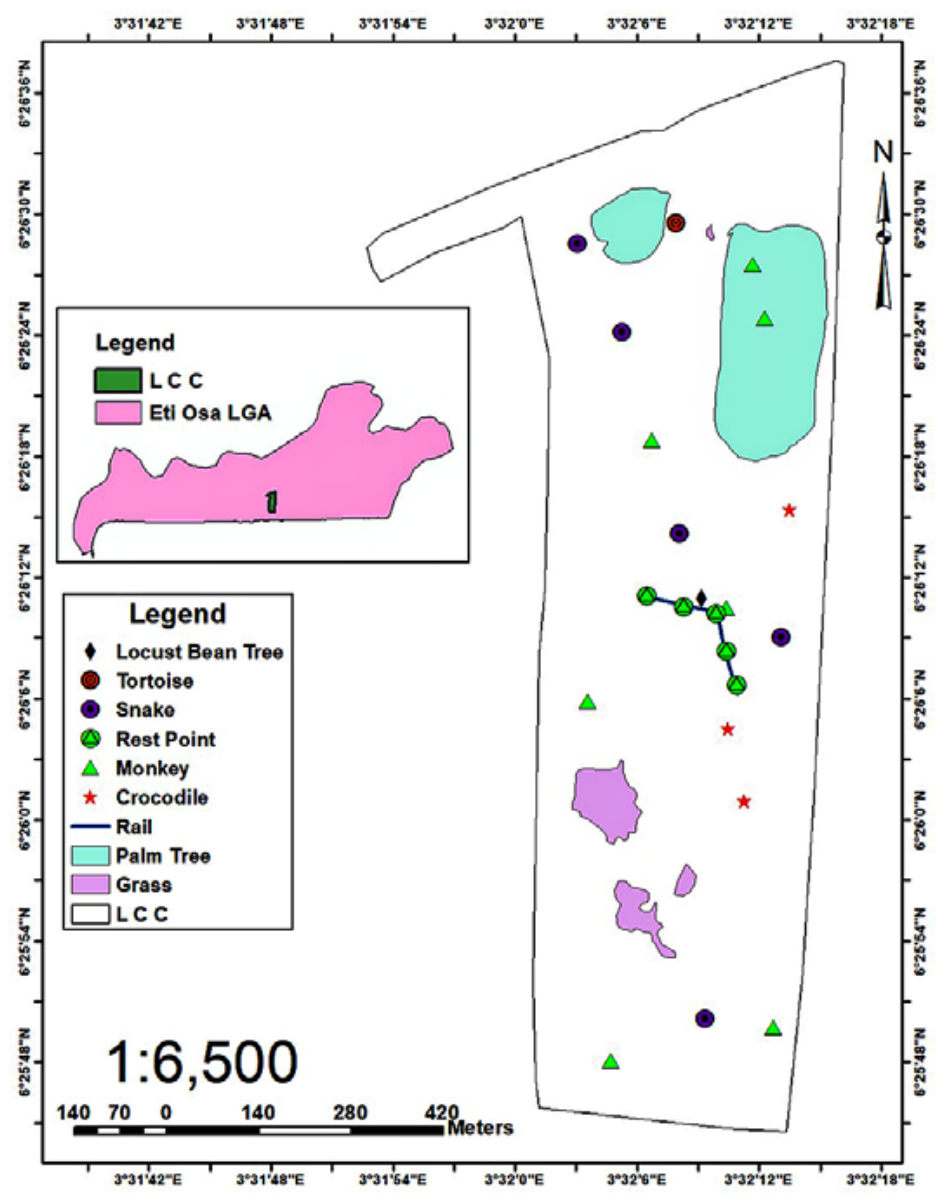

Figure 2. Distribution of species in Lekki Conservation Centre Source: Survey output
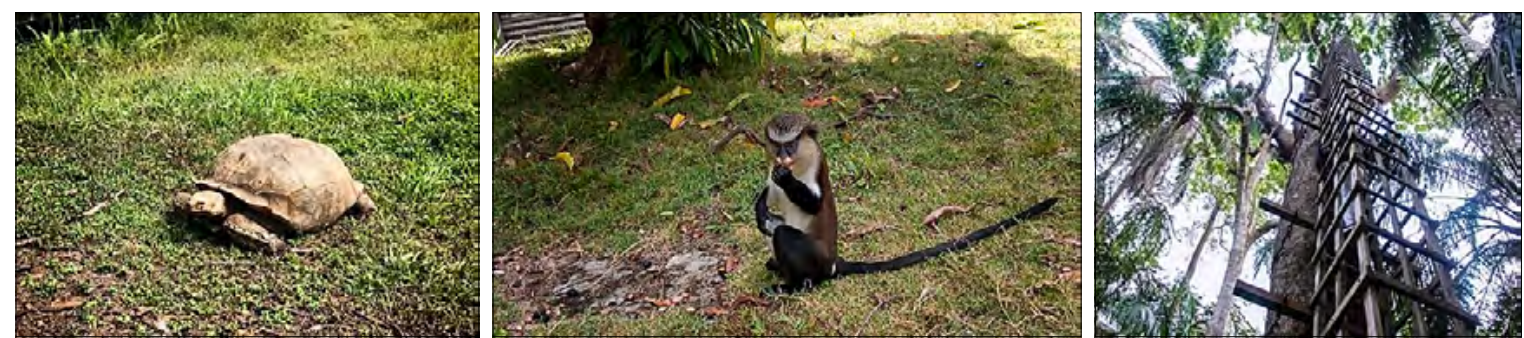

Figure 3. Available species and Tree house Source: Survey output

\section{Other Tourism Assets}

Quality facilities that enhance the visitor experience in the attraction include a tunnel, floor (and other) games, relaxation centre, tree house, family park, jungle gym, Koi and Tilapa Ponds, and canopy walk. The canopy walk at LLC is currently the longest canopy walk in Africa at 410 meters (Figure 3, Figure 4, and Figure 5). 

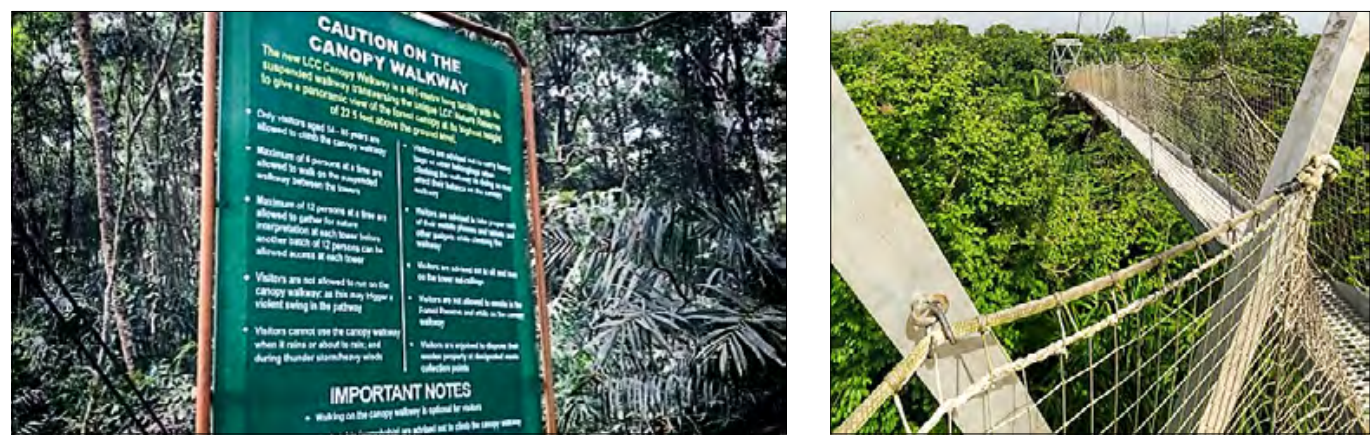

Figure 4. Canopy walk

Source: Survey output
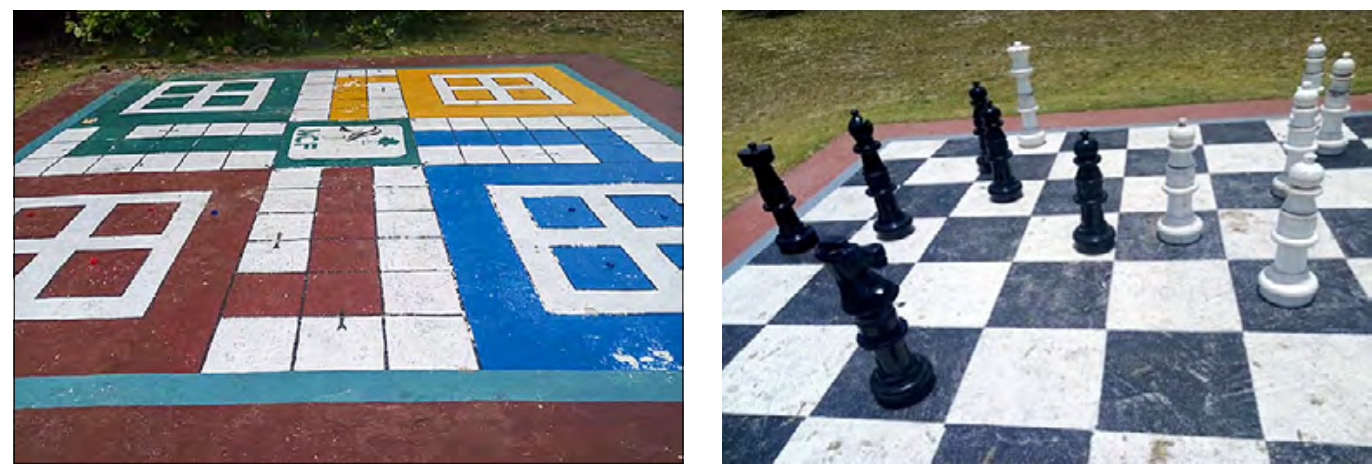

Figure 5. Floor Games

Source: Survey output

\section{Conclusion}

This study has shown that the perception of tourists on ecotourism development in Lagos, Nigeria, with particular reference to Lekki Conservation Centre, is satisfactory and significantly positive for sustainable tourism and destination loyalty. The accessibility attribute of the attraction from the city and other locations, and other indices like low crime rate, receptive indigenous population, and available decent accommodation are perception elements that have given the conservation centre its advantage as an emerging ecotourism destination capable of generating enormous tourism traffic and stimulating economic activities for the benefit of all stakeholders.

The location attribute of the conservation centre is a good factor that positions it as a multidimensional tourist attraction. Its proximity to the lagoons and the Atlantic Ocean is a stimulant for other dimensions of tourism, including marine tourism. The availability of local art and craft, the local market, and tourists' acceptability of culinary service of the destination is favourable to cultural and culinary tourism exploration. The opportunities created through tourists' safety which stimulated regular visitation and that of the receptiveness of the local population which influenced tourists' length of stay are major indicators for sustainable tourism development for economic prosperity. 
Efficient transport is a major impediment to tourism development in the study area. The organized private sector has paid minimal attention where necessary. Traffic efficiency has been allowed to deteriorate due to a lack of synergy between the organized transport sector and the tourism sector, thus affecting the effective movement of tourists where necessary.

The study indicated environmental pollutants (noise and tourist litter) which are unfavourable to tourism development. Destination managers need to understand the negative impact of pollution on tourist destinations and how detrimental it to could be for sustainable tourism. Managers of the attraction have not engaged quality destination management techniques to improve the image of the area, thus allowing the issue of pollution to linger. The non-engagement of destination management technique is a clear indication that adequate synergy has not been created between the attraction and appropriate waste management experts by managers of the attraction to reduce the impact of pollution and the negative perception it could produce.

\section{Recommendation}

Hotels at the destination should form some sort of collaboration with the conservation centre on how to use their chauffeur services for effective tourists' mobility at affordable rates. Since the majority of the tourists lodge in these hotels, the accommodation tariff may also comprise tourism service-related charges including transport to the attraction, where applicable. The charges would assist in curtailing the bottlenecks in tourism transport services, especially when the tour is not packaged.

An orientation mechanism should be put in place by government authorities and the organized private sector to encourage residents of the destination to continue in their receptivity to inbound tourists. The friendliness of residents is a major ingredient to foster inbound visitation, and should be sustained for tourism to prosper.

Priority should be given to environmental management practices by relevant agencies at the destination to foster sustainable tourism. Emphasis should be placed on ecotourism as a major revenue earner for regions. Therefore, collaborative efforts should exist between the attraction and government agencies to ensure the best practices for managing pollution and tourist litter, bearing in mind the impact of pollution on destination loyalty.

Hotels should improve on the provision of the infrastructure component of accommodation, especially internet services for guests' use. Internet services should also be enhanced at the attraction to ensure all-round tourists' satisfaction throughout the tourism experience.

Exotic species from other regions of the country could be introduced to the attraction as a way of improving on the tourism assets. As tourists yearn for more, continuous improvement could be achieved by the periodic introduction of new exotic species of wildlife from farther regions of the country, even on a quarantine or part-time basis.

Tourism products at the attraction could be a full package that would include a blend of the diverse local culture and cuisine as part of the tourism experience, with possibilities of adding visitations to historic sites, and traditional music and dance on the spot. Managers of the attraction should also explore possibilities of expanding the ecotourism potentials of the attraction to marine tourism, having had a competitive advantage with the availability of the Atlantic Ocean at a close distance.

To encourage continuous tourist visitation to the study area, visitors' security should be a major priority for government and other stakeholders at the destination. Government authorities should seize the opportunity provided by the attraction to expand other forms of tourism that would benefit the local people and help in generating micro capital. There should be a syn- 
thesis between economic activities within the area and sustainable tourism development that would ensure increased participation of all stakeholders so that the conservation centre would continue to witness improved tourist traffic daily throughout the year.

\section{References}

Abeli, S.R. 2017. Local Communities' Perception of Ecotourism and Attitudes Towards Conservation of Lake Natron Ramsar Site, Tanzania. International Journal of Humanities and Social Science 7(1), 162-176.

Ajayi, O.O., Eveso, J.O. 2017. Ecotourism in Nigeria: The Okomu National Park Context. Journal of Tourism, Hospitality and Sports 28, 22-33.

Alam, S.S., Sayuti, N.M. 2011. Applying the Theory of Planned Behaviour (TPB) In Halal Food Purchasing. International Journal of Commerce and Management 21(1), 8-20.

Aluko O.E. 2010. The Impact of Urbanization on Housing Development: The Lagos Experience, Nigeria. Ethiopian Journal of Environmental Studies and Management 3(3), 64-74.

Andersson, T., Mossberg, L., Therkelsen, A. 2017. Food and Tourism Synergies: Perspectives on Consumption, Production and Destination Development. Scandinavian Journal of Hospitality and Tourism 17(1), 1-8.

Ares, G., Gámbaro, A. 2007. Influence of Gender, Age and Motives Underlying Food Choice on Perceived Healthiness and Willingness to try Functional Foods. Appetite 49(1), 148-158.

Arowosafe, F.C., Oladeji, S.O. 2017. Visitors Perception Opportunities: A Strategy for Development of Marketing Plan in Kanji Lake National Park, Nigeria. An International Journal of Tropical Environment 14, 1-15.

Artal-Tur, A., Kozak, M., Kozak, N, 2019. Trends in Tourist Behavior: New Products and Experiences from Europe. AG, Switzerland: Springer.

Asbollah, A.Z., Hassan, N., Yusoff, S.Y.M., Idris, H. 2017. The Tourist Behaviour in Different Environments: A Literature Review. Journal of the Malaysian Institute of Planners 15(1), 279-288.

Asuk, S.A., Nchor, A.A. 2018. Challenges of Community-Based Ecotourism Development in Southern Eastern Nigeria: Case study of Iko Esai Community. Journal of Scientific Research \& Reports 20(1), 1-10.

Ayeni, D.A., Ebohon, O.J. 2012. Exploring Sustainable Tourism in Nigeria for Developmental Growth. European Scientific Journal 8(20), 126-140.

Bankole, A.O. 2013. Harnessing Cultural Heritage for Tourism Development in Nigeria: Issues and Prospects. Global Journal of Commerce and Management Perspective 2(3), 121-131.

Bjork, P., Kauppinen-Raisanen, H. 2017. Interested in Eating and Drinking? How Food Affects Travel Satisfaction and the Overall Holiday Experience. Scandinavian Journal of Hospitality and Tourism 17(1), 9-26.

CEIC 2020. Nigeria Visitor Arrivals. Retrieved from https://www.ceicdata.com/en/indicator/ nigeria/visitor-arrivals

Chan, J.K.L., Baum, T. 2007. Ecotourists' Perception of Ecotourism Experience in Lower Kinabatangan, Sabah, Malaysia. Journal of Sustainable Tourism 15(5), 574-590.

Cui, X., Lee, G., Lee, S.J., Kim, T.T. 2019. Structural Relationships Among Antecedents to Perceived Value of Ecotourism for Sichuan Giant Pandas in China. Sustainability 11, 210.

Dabour, N. 2003. Problems and Prospects of Sustainable Tourism Development in the OIC Countries: Ecotourism. Journal of Economic Cooperation 24(1), 25-62. 
Dekhili, S., Achabou, M.A. 2015. The Perception of Ecotourism: Semantic Profusion and Tourists' Expectations. Management \& Human Enterprise 3(19), 1-21.

Dinu, A. 2018. The Importance of Transportation to Tourism Development. Academic Journal of Economic Studies 4(4), 183-187.

Egbulonu, K.G. 2007. Statistical Inference for Science and Business. Owerri, Nigeria: Peace Publishers.

Evans, B. R., Peterson, B.L., Demark-Wahenfried, W. 2004. No Difference in Response Rate to a Mailed Survey among Prostate Cancer Survivors using Conditional versus Unconditional Incentive. Cancer Epidemial Biomarketers \& Preventions 13(2), 277-278.

Figgis, P., Wearing, S., Neil, J. 1999. Ecotourism: Impacts, Potentials, and Possibilities. Massachusetts: Butterworth-Heinemann.

Gisore, R., Ogutu, H. 2015. Sustainable Tourism in Africa: Standards as Essential Catalysts. Sector Standardization Needs Review 9(3), 1-26.

Guri, A. 2016. The Role Of Sustainable Tourism in the Economic Development of Vlora District. European Journal of Research and Reflection in Management Sciences 4(4), 53-62.

Haddle, J.B. 2005. Community Residents' Perceptions of Ecotourism Impacts and Conservation Issues in Rural Creole Belize: A Case Study of Crooked Tree Wildlife Sanctuary (Master's dissertation, University of Florida, Florida, USA). Retrieved from http://plaza. ufl.edu/jbhaddle/haddle j.pdf

Hakim, L. 2017. Managing Biodiversity for a Competitive Ecotourism Industry in Tropical Developing Countries: New opportunities in Biological Fields. AIP Conference Proceedings. Retrieved from https://aip.scitation.org/doi/pdf/10.1063/1.5012708

Han, X., Liu, A., Liu, M. 2017. Noise Perception and its Effects on Tourists' Satisfaction: A Case Study of Nanluoguxiang Lane in Beijing. INTER-NOISE and NOISE-CON Congress and Conference Proceedings, InterNoise17, Hong Kong CHINA, pages 1-1003, pp. 136-146(11).

Handriana, T., Ambara, R. 2016. Responsible Environmental Behavior Intention of Travelers on Ecotourism Sites. Tourism and Hospitality Management 22(2), 135-150.

Idumah, F.O., Onyeanusi, A.E., Akinyem, O.D., Bello, M.A. 2009. Prospects and Challenges of Ecotourism Development in Nigeria. Journal of Environmental Extension 8(1), 15-21.

Ijeomah, H.M., Eniang, A.E. 2018. Ecotourism and National Development in Nigeria. Prospects and Challenges. Proceedings of the 6th NSCB Biodiversity Conference, Uyo, Nigeria, 1-12.

Ijeomah, H.M., Abubarkar, S.I., Ezeano, C.I., Adetola, B.O. 2019. Assessment of Tourist Attraction and Satisfaction in Selected Eco-destinations in Lagos State, Nigeria. African Journal of Agriculture, Technology and Environment 8(1), 85-104.

Jovanović, S., Ilić, I. 2016. Infrastructure as Important Determinant of Tourism Development in the countries of Southeast Europe. Ecoforum 5(1), 288-294.

Juvan, E., Omerzel, D.G., Maravić, M.U. 2017. Tourist Behaviour: An Overview of Models to Date. Management International Conference, Monastier di Treviso (Venice) Italy, May 24-27. Retrieved from http://www.hippocampus.si/ISBN/978-961-7023-71-8/2.pdf

Kiper, T. 2013. Role of Ecotourism in Sustainable Development. In: Özyavuz, M. ed. Advances in Landscape Architecture. Rijeka, Croatia: InTech.

Krelling, A.P., Williams, A.T., Turra, A. 2017. Differences in Perception and Reaction of Tourist Groups to Beach Marine Debris that can Influence a Loss of Tourism Revenue in Coastal Areas. Marine Policy 85, 87-99.

Kyzy, J.D., Öztüre, A. 2018. Perceptions of Tourism Impacts and Sustainability Concept: Insights from Kyrgyzstan. Journal of Tourism Research 19, 254-264. 
Lagos Bureau of Statistics 2016. Abstract of Local Government Statistics. Lagos Bureau of Statistics, Ministry of Economic Planning and Budget, Secretariat, Alausa, Ikeja. Retrieved from https://mepb.lagosstate.gov.ng/wp-content/uploads/sites/29/2017/o1/ ABSTRACT-OF-LOCAL-GOVERNMENT-STATISTICS-2016.pdf

Lau, G., McKercher, B. 2006. Understanding Tourist Movement Patterns in a Destination: A GIS Approach. Tourism and Hospitality Research 7(1), 39-49.

Long, L.M. 2017. Comfort Food in Culinary Tourism: Negotiating "Home" as Exotic and Familiar. In M.O. Jones \& L.M. Long (eds), Comfort Food: Meanings and Memories, pp. 126-149. Jackson MS: University Press of Mississippi.

Maars, M.Y. 2009. Applied Statistics. London: Heinemann.

Marković, I., Klarić, Z. 2015. Attitudes of Local Population of Tourism Impacts on Destination Sustainability - Case of Croatia. International Scientific Journal Turizam 19(3), 98-110.

McGuffin, D. 2017. Describe the Main Elements Of Ecotourism. Retrieved from https://getawaytips.azcentral.com/describe-the-main-elements-of-ecotourism-12311082.html

Morin, C.M., Vallières, A., Guay, B., Ivers, H., Savard J., Mérrette, C., Bastien, C., Baillargeon, L. 2009. Cognitive Behavioral Therapy, Singly and Combined with Medication, for Persistent Insomnia: A Randomized Controlled Trial. JAMA, 301(19), 2005-2015.

Nigerian Conservation Foundation 2016. 2016 Annual Reports and Financial Statements. Retrieved from https://www.ncfnigeria.org/Reports/2016\%20NCF\%20Annual\%2oReport. pdf

Nwokorie, E.C., Adiukwu, I.K. 2020. Hospitality and Tourism Entrepreneurship: Administrative Barriers in Imo State, Nigeria. International Scientific Journal Turizam 24(1), 13-32.

Nwokorie, E.C., Igbojekwe, P. 2019. Security Challenges for the Hotel Industry: Implications for Selected Hotels in Owerri, Nigeria. Academica Turistica - Tourism and Innovation Journal 12(2), 193-205.

Nwokorie, E.C. 2017. Impact of Organizational Conflict on Employee Job Performance in Selected Hotels in Lagos Nigeria. International Scientific Journal Turizam 21(1), 45-64.

Nwokorie, E.C. 2015. Food Tourism in Local Economic Development and National Branding in Nigeria. HATMAN Journal of Hospitality and Tourism 5(1), 20-26.

Nwokorie, E.C., Obiora, J.N. 2018. Sustainable Development Practices for the Hotel Industry in Nigeria: Implications for the Ilaro Area of Ogun State. Research in Hospitality Management 8(2), 125-131.

Nwokorie, E.C., Everest, D.A., Ojo, O.O. 2014. Emerging Security Challenges for Tourism Development: Effect on the Nigerian Economy. Journal of Women in Technical Education 7(2), 33-40.

Obiora, J.N., Nwokorie, E.C. 2019. Enhancing Destination Loyalty through Online Presence in the Tourism Industry in South-East Nigeria. Accounting and Taxation Review 3(1), 69-81.

Oohlala, R. 2013. Sustainable Tourism: Sustainable and Responsible Development. Retrieved from https://www.slideshare.net/reymarieoohlala/sustainable-tourism-28775238

Orimaye, J.O., Ogunjinmi, A.A., Ogunyemi, O.O., Okosodo, E.F., Kolawole, O.O., Daramola, D.O. 2018. Residents' Perception of Ecotourism Impact in Ekiti State: A Case Study of Ikogosi Warm Spring. Agricultural Extension Journal 2(2), 144-150.

Padin, C. 2012. A Sustainable Tourism Planning Model: Components and Relationships. European Business Review 24(6), 510-518.

Prideaux, B. 200o. The Role of the Transport System in Destination Development. Tourism Management 21(1), 53-63. 
Roy, B., Saxena, A.K. 2020. Destination Competitiveness, Tourism Facilities and Problems in Promoting Uttarakhand as a Tourism Destination. Journal of Tourism, Hospitality $\mathcal{E}$ Culinary Arts 12 (2), 1-20.

Salako, T.E., Oyeleke, O.O., Ogunjimi, A.A. 2018. Assessment of Guided Tour on Visitors' Behaviour in Lekki Conservation Centre and Osun Osogbo Sacred Groove, Osogbo, Osun State. Journal of Sustainable Technology 9(1), 89-98.

Sandaruwani, J.A.R.C., Gnanapala, W.K.A.C. 2016. The Role of Tourist Guides and their Impacts on Sustainable Tourism Development: A Critique on Sri Lanka. Tourism, Leisure and Global Change 3, 62-73.

Sangpikul, A. 2020. Tourist Perceptions of Guided Ecotourism Tours in Thailand. Tourism and Hospitality Research 2o(2), 245-256.

Santos, C., Silva, D., Amorim, E. 2018. The Impact of Tourism Security on the Image of the Destination - The case of Portugal. Journal of Tourism Research 19, 207-216.

Schawnms, R.C. 1994. Advanced Statistics: An Introduction. London: Knightbridge Publications Ltd.

Stronza, A., Hunt, C., Fitzgerald, L. 2019. Ecotourism for Conservation? Annual Review of Environment and Resources 44, 229-254

Stronza, A., Pegas, F. 2008. Ecotourism and Conservation: Two Cases from Brazil and Peru. Human Dimensions of Wildlife 13, 263-279.

Sorupia, E. 2005. Rethinking the Role of Transportation in Tourism. Proceedings of the Eastern Asia Society for Transportation Studies 5, 1767-1777.

TIES 2015. What is Ecotourism? Retrieved online on February 10, 2020, from https://ecotourism.org/what-is-ecotourism/

Ukabuilu, E.N., Nwokorie, E.C., Ezeibe, N. 2018. Empirical investigation of Problems of Inbound Tourism in South-Eastern Nigeria: Catalyst for Regional Development. HATMAN Journal of Hospitality and Tourism 8(1), 29-35.

UNEP, UNWTO. 2005. Making Tourism More Sustainable - A guide for Policy Makers, Paris, France \& Madrid, Spain: UNEP \& UNWTO.

UNWTO. 2017. UNWTO Tourism Highlights, 2017 Edition. Retrieved online on August 25, 2019, from https://www.unwto.org/archive/global/publication/unwto-tourism-highlights-2017

Ursache, M. 2015. Tourism - Significant Driver Shaping a Destinations Heritage. Procedia Social and Behavioral Sciences 188, 130-137.

Vengesayi, S., Mavondo, F.T., Reisinger, Y. 2009. Tourism Destination Attractiveness: Attractions, Facilities, and People as Predictors. Tourism Analysis 14, 621-636.

World Data Atlas. 2019. Nigeria: International Tourism, Number of Arrivals. Retrieved from https://knoema.com/atlas/Nigeria/topics/Tourism/Key-Tourism-Indicators/Number-of-arrivals

Yamada, N. 2011. Why Tour Guiding is Important for Ecotourism: Enhancing Guiding Quality with the Ecotourism Promotion Policy in Japan. Asia Pacific Journal of Tourism Research 16(2), 139-152.

Yamane, T. 1967. Statistics: An Introductory Analysis (2nd Ed.). New York: Harper \& Row.

Zhuang, X., Yao, Y., Li, J.J. 2019. Sociocultural Impacts of Tourism on Residents of World Cultural Heritage Sites in China. Sustainability 11, 840. 